\title{
41919
}

\section{Is there, for the black person, only one destiny? \\ A psychoanalytical approach}

\author{
Jefferson Nascimento \& Giselle Falbo
}

\begin{abstract}
:
This paper intends to think about how racism interferes in building the image of the black person in the process of subjective constitution, in its articulation with the discourse of the Other, as conceived by Jacques Lacan in his work, namely, as unconscious and its manifestations at the cultural level and at the level of the social bond. To this end, we will refer to the theoretical elaborations of Neusa Santos Souza, Frantz Fanon, and Grada Kilomba, authors who undertook, each in their own time and their respective readings and social contexts, powerful reflections on racism from a psychoanalysis standpoint. Through the conception of language as proposed by Lacan and the concept of blackness in Munanga, we indicate how the issue updates itself in Brazil today. To conclude, understanding that there is psychic suffering engendered by this mode of segregation, we suggest alternatives and ways that articulate the empowerment of the subject that crosses and is at the same time crossed by the collective.
\end{abstract}

Keywords: Blackness; racism; psychoanalysis; image; subjective constitution.

\section{Resumo:}

Este artigo pretende refletir sobre como o racismo interfere na construção da imagem da pessoa negra no processo de constituição subjetiva, em sua articulação com o discurso do Outro, como concebido por Jacques Lacan, a saber, como inconsciente, e suas manifestações no nível cultural e no nível do laço social. Para tanto, faremos referência às elaborações teóricas de Neusa Santos Souza, Frantz Fanon e Grada Kilomba, autores que empreenderam, cada um em seu tempo e suas respectivas leituras e contextos sociais, reflexões poderosas sobre o racismo, do ponto de vista da psicanálise. Por meio da concepção de linguagem proposta por Lacan e do conceito de negritude em Munanga, indicamos como a questão se atualiza hoje no Brasil. Para concluir, entendendo que há sofrimento psíquico gerado por esse modo de segregação, 
sugerimos alternativas e formas que articulam o empoderamento do sujeito que atravessa e é, ao mesmo tempo, atravessado pelo coletivo.

Palavras-chave: Negritude; racismo; psicanálise; imagem; constituição subjetiva.

\section{Introduction}

To begin our argument, we bring the definition of racism - as proposed by Kabengele Munanga (2004) - as the belief in the existence of naturally hierarchized races by the intrinsic relationship between the physical characteristics of a certain ethnicity and moral conduct, intellect and cultural manifestations. According to the author, from a sociological point of view it is the racist who creates racism. In other words, race, in the racist's mind, is not exclusively a group defined by physical traits. Race is much more. It is also a social group with cultural, linguistic, religious and other traits that the racist considers naturally inferior to those that characterize the group to which he belongs. In this sense, racism is this tendency to consider that the intellectual and moral characteristics of a given group are direct consequences of its physical and/or biological characteristics.

From this point of view, we intend to pinpoint racism as a way of thinking that has consequences and that, among them, makes it difficult for the black person to constitute himself as a subject outside a situation of "inferiority complex" (Fanon, 2008). It is a complex that, in this case, establishes itself in an otherness relation between the black and the white. Fanon (2008) departs from the relations between blacks and whites in the countries "colonized"1 by Europe, specifically in his nation of origin: Martinique. Among the many psychic effects of this relationship, we highlight situations in which the black person needs, in special, to reconsider their human condition in order to stop feeling like a "piece" or "thing" - such as pointed out by Nogueira (1998). We emphasize that it is possible to pinpoint, in the life of the black person around the world, social and historical origins that justify such perception. We can cite here, as an example of black person reduced to the condition of piece or object, a clipped fragment of a manual published in 1839 - written by IBA Imbert - which aimed to guide the purchase of black slaves and which we find in the article Ser peça, ser coisa: definições e especificidades da

\footnotetext{
${ }^{1}$ The term "colonized" appears in quotation marks to mark the existing controversy in the term. In the post colonialist and decolonial perspective, people from the American, Asian, African and Oceania continents were not "colonized"; but went through a violent process of acculturation and had their natural goods expropriated, besides being forced to serve the European man.
} 
escravidão no Brasil (Being part, being thing: definitions and specificities of slavery in Brazil) by Schwarcz:

(...) Circumstances to be considered by anyone who wishes to make a good choice of slaves: smooth, non-greasy skin, beautiful black color, free from stains, excessive scars or strong odors: with properly developed genitals: that is, neither sinned by excess or quainness; the underbelly should not be too prominent; not should the belly button be bulky; long, deep, resonant chest, strong shoulders, a sign of well-placed lungs, neck in fair proportion to stature, strong and compact muscles; aspect of ardor and liveliness: these traits combined will be found in a slave who will present to the master all the desirable guarantees of health, strength and intelligence (1996: 14).

Another example that illustrates well the difficulty of black people placing themselves as subjects in a society that reserves for them the place of an object appears in Sojourner Truth's famous speech Ain't I A Woman. On May 29, 1851, Sojourner, a feminist black woman, an abolitionist and advocate of women's rights, made an impactful speech at the Convention for the Rights of Women in Akron, Ohio, United States of America:

That man over there says that women need to be helped into carriages, and lifted over ditches, and to have the best place everywhere. Nobody ever helps me into carriages, or over mud-puddles, or gives me any best place! And ain't I a woman? Look at me! Look at my arm! I have ploughed and planted, and gathered into barns, and no man could head me! And ain't I a woman? I could work as much and eat as much as a man - when I could get it - and bear the lash as well! And ain't I a woman? I have borne thirteen children, and seen most all sold off to slavery, and when I cried out with my mother's grief, none but Jesus heard me! And ain't I a woman? (National Park Service, Women's Rights, 2017, 2 September).

Sojouner's speech allows us to attest to the subjective impasse of black women in face of the way the problems posed by white feminism were lived. Sojouner is precise in her point of view and can give back to the interlocutor (perhaps the oppressor) the question that plagues her: "And I am not a woman?" Which in this context resonates: And I am not human? Am I a thing, an object?

In the book Black Skin, White Masks, originally published in 1952, we come across many situations in which this distinctive way of dealing with anatomical differences or, should we say, of gathering their psychic consequences, is updated. In the way such differences are interpreted, we almost always see the black person in an inferior or subservient 
position in relation to the white person. In the chapters "The Woman of Color and the White Man", "The Man of Color and the White Woman", and "The Living Experience of the Black Person", Fanon spells out the modus operandi of a white society towards the black subject. In the first chapter, he analyzes the work Je suis Martiniquaise by Mayotte Capécia. Fanon presents her biography, which is marked by her relationship with a man from whom anything was accepted. Her love relationship with him was permeated by the image portrayed by this man: that of whiteness and all the positive attributes associated with it. Mayotte Capécia stated that she "loved him because he had blue eyes, blond hair and fair skin (Fanon, 2008: 54)". At some point she describes an uncomfortable situation she experienced by his side because of the color of her skin:

Some nights, alas, he left me to fulfill his mundane obligations! He went to Didier; the upscale neighborhood of Fort-de France, home to the Martinique bourgeoisie, who may not be very pure but who are often very wealthy... Among André's friends who, like him, found themselves immobilizes in the Antilles because of the war, some had managed to bring their women. I understood that André could not be always isolated. I also accepted not to be received in this environment because I was a woman of color, but I couldn't help being jealous. As much as he explained to me that his intimate life was something that belonged to him, but that his social and military life was another life which he did not control, I insisted so much that one day he took me to Didier. We spent the night in one of those villas I had admired since childhood, with two officers and their wives. They looked at me with unbearable indulgence. I felt like my makeup was heavy, that I wasn't dressed properly, that I wasn't up to André, maybe just because of my skin; In short, I spent such an unpleasant night that I decided never to ask André to join him again (Fanon, 2008: 150).

We may say that Mayotte's sensation is perpetuated to this day in various, but related, ways. One can see an update of this sense of non-belonging, of being marginalized, in the most diverse societies in which black people were forcibly introduced by the diaspora process. In the Brazilian context, as we will see later, the black person often occupies a stigmatized and marginal place, often being associated with the criminal, a reference to "that" which is not of use: the rest. And that, as waste, must be eliminated. As a result, black people live in a different condition when compared to white people, with fewer rights and more exposed to state violence, which may engender the subjective dilemma of being or not being as human as a white person. It is important to note that, from the perspective of psychoanalysis, waste is strictly related to building the figure of the ideal. According to Miller: 
Waste is what is rejected and especially rejected after an operation where only gold is retained, the precious substance to which it leads." In this respect the psychoanalyst further adds: "(...) it is what falls, is what falls when, on the other hand, something rises. It is what is evacuated, or made to disappear while the ideal shines. What shines has form. One may say that the ideal is the glory of form while waste is formless. It prevails over a totality of which it is only a piece, a loose piece (2010: 2 ).

This articulation between the rest, the waste, and the ideal unveils the psychic process at stake in the way some societies conceive of the black subject, locating it as waste in relation to which the white being shines as the precious substance. This position that is articulated from the point of view of the Other, as described by Lacan (1998), engenders as a result a society that favors the construction of fantasies in which the black is situated in a stigmatized place as waste. As a result, black people find ways of dealing with this look that include a certain conformity with this place reserved for them, since before birth, in the Other - which can lead them to dialogue and identify themselves with this position of wasteful object (Lacan, 1995) - or to rebel and oppose this logic, trying to construct other frames and new possibilities of existence. In this sense, we ask ourselves: what image of oneself could be built for those who do not consent to identify with the criminal, the hypersexualized, devoid of intellect, which constitute the places mostly reserved for black people in the Brazilian society?

As is well put by Munanga (2004), racism is no longer justifiable by arguments based on the supposed biological differences - although these have been adopted against the black population and left deep marks on the social imaginary - today it updates itself on the policies implemented by capitalism and in the expansion of the death camps, as pointed out by Mbembe (2018). By making use of the concept of necropolitics, this author frames the power to dictate who should live and who should die. It is a power of determination over life and death by destroying the political status of the subjects, and this is very noticeable in the relationship of the state - a situation quite evident in the current Brazilian context, as we will see later, regarding the black population. We can also observe, in many cases, the reduction of the black person to their body - in situations of hypersexualization of the body of women and men, the deliberate murder of young people, the myth that the black body is more resistant to work etc. Such circumstances dehumanize the black person and make room for all kinds of arbitrariness. Mbembe (2018) also points out that the use of these techniques and the development of meticulously designed apparatus for the execution of this policy of disappearance and death generates the extermination of certain bodies of people who eventually have no 
place in the system. It is therefore a policy that literally starts from exclusion and segregation towards extermination.

In this paper we ask ourselves: how to interfere in this predetermined destiny for the black population? In this confrontation, the production of actions that make room for the resignification of the images on which the racist discourse is mounted is regarded as fundamental. These images, we highlight, have significant value that compose a language. We will call language here not only what communicates something to someone, but also that which constitutes us as human beings. Language is not only taken as something that is verbalized, that is, something that is spoken and/or written. It has a dimension of enunciation, transmitted through nonverbal elements, expressed in gestures, drawings, music, paintings, mimes, silences, dreams, etc. Over time a popular imagination was created, almost a mythology of what it is to be black. And this "mythology" directly prevents the black person from approaching what Lacan's theory frames as the subject of desire. Because of being socially situated in the place of object and/or commodity, the black person may find it difficult to move from the place of subject situated in the position of object to become a desiring subject.

Briefly, for psychoanalysis, we can say that subjectivity is divided into orders of operation, concerning the conscious, the preconscious and the unconscious mind, being essentially constituted by the second. The subject of psychoanalysis is the subject of desire, outlined by Freud by means of the notion of the unconscious mind, marked and driven by lack distinct from the biological being and the subject of philosophical consciousness. This subject is constituted by the insertion in a symbolic order that precedes him, crossed by language, taken by the desire of the Other and mediated by a third. The symbolic order crosses and constitutes the subject, which arises in response to this preceding speech. In this sense, it is essential to consider the transgenerationality of signifiers that will be collected from the field of the Other and which will guide the subject in his destiny and choices.

In our argument, we take as main reference the theory of Martinique psychiatrist Frantz Fanon and also the Brazilian psychiatrist and psychoanalyst Neusa Santos Souza, respectively in the aforementioned works Black Skins, White Masks (2008) and "Tornarse Negro: As Vicissitudes da Identidade do Negro Brasileiro em Ascensão Social" (Becoming Black: The Vicissitudes of Black Brazilian Identity in Social Rise) (1983). Both are black and, although of different nationalities and eras, were concerned with outlining the architecture of the subjectivation processes of blacks and whites affected by racism. The theoretical convergence of their respective work led us to the following question: what image will the colonized or socially rising black man take for himself as a reference to be reached? Both understood that this model, due to the socio-cultural context and 
colonization, is white, which represents and engenders a series of problems for the subject. They present us with a way out of the impasse facing the black in an attempt to respond to the desire of the Other who, in these contexts, tend to conform to an ideal of whiteness, as stated by Fanon (2008: 22): "For the black person, there is only one destination. And it is white".

\section{1- Who is the white?}

According to Souza the white person is: "the aristocrat, the successful, the intelligent, the literate...", she further adds that "under any circumstances, white is the model to be chosen" (1983: 34). According to the author, this marks for blacks a "singular choice, fixed by default for those who should only configure themselves to such a model" (Souza, 1983:34). The dynamics of this psychic relationship between the one who is elected as ideal and the remaining part as waste occurs, as explained earlier through Miller's observations. Reading Fanon's work (2008), we can see that such a situation is so because white colonial cultures equate "blackness" with inferiority: it is therefore the racist who creates the inferior. Trying to escape the undervalued position reserved for them, black people often find in the rejection of the characteristics which are the components of their blackness, most of them elected by the white, the only way out of their condition and into acceptance. As Souza (1983) has pointed out, the definitions that cross the imagination and concern the white person indicate something positive and those that refer to being black, do not. This relationship is noticeable in the various associations made to the black signifier in the use of language itself, whether in newspapers, advertisements, music, arts, literature and other fields. As stated earlier, being white is also occupying the place of being able to tell who dies or not, is having the power to put the black body into segregation and subsequently kill it.

\section{2- Considerations on the psychic suffering of the black person}

In Fanon's work (2008), we highlight several reports in which it is possible to perceive the collectivized part of the psychic suffering to which the black person is subjected, in a social structure in which the white person occupies the ideal model of existence. This "white world" brings very specific references of how to be human, and which go through an imagetic pattern that places the white subject as reference, a model to be achieved. In the reports obtained by Souza (1983), in the interviews that fueled her research, we notice the black person suffering from the realization that they can never become white. One notices, therefore, the disastrous psychic consequences of the interpretation given to the anatomical differences between whites and blacks. 
Fanon, agreeing with Souza's later studies, states that there are theories “... that made black halfway in the development of the ape to man" (2008: 33). At certain point it is possible to notice that, for a good portion of society, black is not even the "midway", he is still considered the monkey or ape itself, as we see in the many stories that involve racist name callings. As an example, we can mention, among many others, a case that gained great repercussion in Brazil from the soccer player, Aranha, who was the target of racist comments when he was called "monkey" by the fans in the game of Grêmio, in 2015. Souza (1983: 28) brings several situations through the accounts of her interviewees in which she marks how the subject is crossed by such signifiers: "I considered myself black: going places and knowing that I was different from others. I was black, but different: I could hold a fork, I wasn't a monkey, I could play the piano...." The interviews also demonstrate how being dirty is associated with black people:

"My grandmother didn't like black people. She said that "crioulos"2 were no good: If you see confusion, know that it is the black who is responsible for it; if you see a black man run, he is a thief. You have to marry a white man to clean the womb" (Souza, 1983: 30).

This account is interesting because it points to what Fanon (2008) calls the understanding of the for-the-other dimension of the colored man. In the popular imagination, the black is always the first suspect of a crime, if not the only one.

Many are the situations that elucidate this statement and we can report some that illustrate well this "common sense" about what it is to be black to this white Other. Recently, in Brazil, a family of black people were shot 80 times by the Brazilian army. The military saw a black man on board and assumed he was a drug dealer; and not only shot him, but his whole family also, and riddled the car with bullets. Still in Rio de Janeiro, a man who was working on the roof of a house was shot by the police who, because of his color, silhouette and carrying a hammer, was "mistaken" for an armed criminal. Such episodes, which happen almost daily in the current Brazilian reality, inform us and attest to the place given to the black: the marginal. We also remember that marginal is also that which is on the edge in relation to the center. And who would be the center? The white, to whom the good qualities are attributed in the popular imagination.

Influenced by this mode of operation and trying to free himself from this stigma, the black person undertakes an exhaustive struggle to deny their blackness, which often goes through non-acceptance, and may even attempt to transform his negroid physical traits, the erasure of his ancestry, the choice for descent miscegenation as an attempt to

\footnotetext{
${ }^{2}$ Crioulo, in Brazilian Portuguese, is a term often pejoratively used to refer to black people born in Brazil.
} 
"lighten" their family, among other disorders. We may call this aspiration - guided by whiteness - as an unfortunate and disastrous search for an idea, an ideal of the Self. Disastrous, because it entails countless sufferings. We recall here that the term ideal of the Self is Freudian and refers to a guiding model, from which the subject is constituted. In many cases, this model is cast as an ideal of perfection, or almost. It is worth mentioning here a few words about the subjective constitution, as conceived by Freud and Lacan, so that we can better follow the theoretical elaborations of Neusa Santos.

According to Lacan's reading of Freud, the subject, even before birth, is anticipated in the parental couple's discourse. This anticipation gives it a place in the desire of the Other and is guided by the needs and projections of the parents, in face of which he will emerge in response. At first, the infans still have no control over their body, which will only establish itself as a unit from identification to his self-image projected and anticipated by the gaze of the Other. It is this new psychic action, the identification in the image of itself as a unified body, that will build narcissism in the figure of an ideal self. This ideal self is only a projection, a Gestalt to which are attributed the perfections that provide the rescue of the lost narcissism of parents and that places the baby in the position of "His majesty". As a result of the comings and goings of the maternal Other and, later, with the disappointments and criticisms that come from others, the identification with the image of the ideal self is gradually corrupted and questioned. But since the subject does not easily give up on a satisfaction once the libido has come to fruition, the subject builds a new version of the ideal, an ideal of the self, less integral and more emptied than the Gestalt that cuts through the ideal self. Although in Freud the distinction between these two instances is not so clear, with Lacan, we can say that the ideal self is a first surface that concerns the imaginary, while the ideal of the self refers more to the significant traits, that is, of a symbolic model that will guide and guide the future choices of the subject. The ideal of self will be edified by the symbolic marks collected from the Other, from the cultural melting pot that feeds it. It is, therefore, transgenerational. The distance between the ideal of the self and the present self is measured by the critical instance, the superself. The psychic dynamics at stake here is: the closer the subject is to his ideals; the more satisfaction he enjoys. On the other hand, the greater the distance from the ideal, the greater the feeling of guilt which is its subjective translation. Having digressed a little, we will now return to the psychoanalyst's theorizing in order to locate the impasses of this process in the case of the subject who is black in a Eurocentric and whitenessoriented cultural context.

Souza (1983) defends that, from the point of view of psychoanalysis, the ideal of the Self for the black is white and that the unfolding of this for the diasporic black is an eternal situation of psychic torment, since he or she can never reach such an ideal (that passes 
through the real - in the lacanian sense - of color). We perceive as an effect of this search a psychic suffering that results in the attempts at body, cultural and other modifications mentioned before which are linked to the network of signifiers that are associated with the term "black". With Fanon's help, we can hear why the black person might go down this path: "Even exposing myself to the resentment of my colored brothers, I will say that the black is not a man (Fanon, 2008: 26)".

In the social construct in which we are inserted, the black could not originally be a man because the conception of what is a human being is based on the philosophical precepts of an originally white society, that sees and recognizes itself as holder of the "civilization" and bearer of the knowledge of what it is to be human. In doing so, it misrepresents any cultures that differ from theirs. In order to illustrate how serious this issue is in Brazil today, we quote from the current President of the Republic, while still campaigning for office. At the time, speaking to his prospective voters, he said when referring to the quilombola community: "I went to a quilombo. The lightest African descendant there weighed seven arrobas (a measure used to weigh cattle). They do nothing. I don't even think he is good for breeding anymore." It is clear, in the speech of the one who currently holds the presidency of the Brazilian Republic, the unequivocal approach of the black to the animal, cattle. And to the extent that this speech is not enough to abort his project to occupy the top position in the Brazilian executive power, it becomes evident that it translates something that is deeply rooted in the culture of the country that, for many years, disguised its racist dimension by making use of the myth of an alleged racial democracy. This myth, according to Kabengele Munanga (2004), was even responsible for hiding the recognition of the damage that the miscegenation caused to black people in Brazil, hindering the struggles for social justice and for an equitable redistribution of the collective product.

\section{3- Clinical and political alternatives to questions posed by the diasporic blacks}

Knowing you are black is living the experience of having been massacred in your identity, confused in your expectations, submitted to demands, compelled to alienated expectations. But it is also, and above all else, the experience of committing yourself to rescuing your history and recreating yourself in your potentialities (Souza, 1983: 17-18)

As indicated in the epigraph chosen to open this part of our text, there is a very potent duality in the experience of knowing you are black. It is interesting to note that this expression "knowing you are black", in the Brazilian case, holds specificities, since we 
are a country in which racism was eluded by the myth of racial democracy. Many of us suffer the consequences of this dynamic in the social bond without, however, realizing that we suffer the psychic effects of this segregation, which in many cases affects them entirely unconsciously. So we ask ourselves, "How do we, I mean psychoanalysts, respond to the fact that segregation has been put on the agenda by an unprecedented subversion?" (Lacan, 2003).

Grada Kilomba (2019) defines the idea of decolonization as an act of getting rid of colonialism. The term refers to the conquest of autonomy by those who have been 'colonized' and, therefore, can easily be applied to the context in which racism is inserted. In the author's opinion, daily racism establishes a dynamic similar to that of colonialism itself. She describes the situation of how a black person is looked at, how they are addressed: they are beaten, wounded and finally imprisoned in a white imaginary that imposes what they should be. A clinic that pays attention to the processes of racial segregation and its effects on the suffering of the black person is a matter for everyone, including - above all in Brazil - psychoanalysis. It is not a matter of being a "pamphleteer", but of being aware of that subject's singular suffering in the face of the discontentment that is collectivized in some dimension. Silva (2017) says that psychoanalysis is also characterized by the fact that it turns history into past, since it is not past until it is elaborated, that is, remembered so that it can be forgotten... In other words, for as long as these questions are not elaborated, they will remain unknown, not localized and causing damage.

Kilomba (2019) presents a clinical proposal called "decolonization of the self" where the author rereads the mechanisms of defense of the Self pointed out in the first Freudian topic as follows: denial/frustration/ambivalence/identification/decolonization. Like Silva (2017), she understands that remembering is the beginning of treatment, as it outdates the past, temporalizes it. Kilomba (2019) after a careful and contextualized description of the mechanisms that guide the proposal of decolonization of the Self, highlights and problematizes the trauma in psychoanalysis by pointing out that, in general, psychoanalysts rarely discuss racism as trauma. In line with the author's position we understand that "... the disciplines of psychology, in particular psychoanalysis, have largely neglected the history of racial oppression and the psychological consequences suffered by the oppressed" (Kilomba, 2019: 215). The author defines trauma as a violent event in the subject life. Daily slavery, colonialism, and racism necessarily contain the trauma of an intense and violent life event, an event for which culture does not provide symbolic elements hindering the work of black subjectivation.

From what has been exposed so far, we ask ourselves: what are the possibilities for black people to reposition themselves in this context that is so averse to them? How to 
build a new destiny, different from the one left to them by the marks of servitude? We consider that this confrontation needs to be done in different spheres, both politically and within the scope of the singularity. And the psychoanalyst Souza points to this when she tells us that being black is:

\begin{abstract}
...becoming aware of the ideological process that, through a mythical discourse about oneself, engenders a structure of ignorance that imprisons the person in an alienated image in which they recognize themselves. Being black is taking possession of that consciousness and creating a new consciousness that reassures respect for differences and reaffirms a dignity outside any level of exploitation (1983: 77).
\end{abstract}

In other words, in the subjective plane in its articulation with the collectivity, she presents two paths: to become black or to be consumed in efforts in the unsuccessful attempt to fulfill another's impossible desire - to be white.

Kabengele Munanga (1990), in turn, proposes that in the act of breaking with slavery and colonial system, black people realize that their "salvation" is not in the pursuit of assimilation of the white, but in what he calls "taking back what is yours". He points out elements that go through the cultural, moral, physical, intellectual affirmation and the historical rescue of black civilizations as constituents of this process of retaking. He calls this act of taking back what is your blackness. Both Munanga and Souza point to the possibility that blacks see themselves outside the stigma: piece and thing that go through a becoming. An act of sliding of the subject through many places and signifiers. And such an initiative concerns the act of empowering oneself. According to the Michaelis dictionary "empowering" means: investing power in order to promote actions that can bring about positive changes in the social group. This investment of power in oneself, from the perspective of empowerment, has consequences for the group to which this subject belongs and may become a promoter of the hegemonic image breakdown that society has about the black subject.

In the preface to Souza's book, Costa (1983) states that: "For the subject to construct statements about his identity, in order to create a harmonious psychic structure, the body must be predominantly lived and thought of as a place and source of life and pleasure" (1983: 6) Empowerment bets on body aesthetics, that is, on taking on your negroid traits as a path towards becoming someone from your image. There is also a broadening of the term for words that concern the black, formerly inserted into a racist enunciation. Berth (2019) points out that the use of aesthetics, although widely criticized by many people, plays a fundamental role in what we can understand as constitution of the subject. In psychoanalytical clinic, the appropriation or use of the images (signifiers) 
brought about by empowerment can bring other possibilities for the subject to start seeing himself. In the understanding that empowering is paradoxically singular and collective, Berth (2019) points out that when we talk about empowerment, we are talking about something that has a political essence, but goes through all the areas of that form the subject and all the nuances that involve the collectivity.

Nogueira (1998) states that countless works have contributed to the elaboration of the black subject's life condition. This has also happened through historiographical investigations that account for the genesis and institutionalization of the slave status and the origins of imaginary representations linked to the "black" figure. At the same time, we see the unveiling of the processes that lead to the construction of the "ideal of whiteness". Such studies focus on the current situation of the black population and seek to explain this situation in function of the historical determinants and cultural injunctions that would be responsible for a certain social place that currently identifies the black in society.

\section{Conclusion}

To conclude, as a way out of the subjective impasse in which the black was put, we propose the expansion and affirmation of actions that intertwine the subject to a network that is attentive to colonialist and segregationist processes. We reaffirm that racism is a language-related issue and that, to intervene in this discontentment, it is also important to invest in how the black person appears hegemonically in language mechanisms. It is important make it clear that we refer not only to the presence of black people in situations of visibility, but to a world perspective that is anti-racist, that is, that pays attention to and that denounces the structural processes that segregate the black person. The effects of these interventions can be made effective, from the subjective point of view, with the perception of an enlargement of places and imagetic framings of what it is to be black: in the arts, education, politics and how possible it is for this subject to listen to himself. From the uniqueness of each member who reconstructs her/his image in the writing of another narrative of her/himself, the collective committed to breaking the hegemonic image gains strength. Thus, we follow Souza (1983) when she proposes that being black "... is not a given condition, a priori. It is a becoming. To be black is to become black".

\section{References}

Berth, J. (2019). Empoderamento. São Paulo: Sueli Carneiro; Polén.

Capécia, M. (1948). Je suis Martiniquaise. Paris: Corrêa. 
Costa, J. F. (1983). Da Cor ao Corpo: a Violência do Racismo. In Souza, N. S. (Ed.) Tornar-se Negro: As Vicissitudes da Identidade do Negro Brasileiro em Ascensão Social (pp.1-16). Rio de Janeiro: Edições Graal.

Fanon, F. (2008). Pele Negra e Máscaras Brancas. Salvador: EDUFBA.

Kilomba, G. (2019). Memórias da Plantação: Episódios de Racismo Cotidiano. Rio de Janeiro: Cobogó.

Lacan, J. (1995). O seminário, livro 4: a relação de objeto. Rio de Janeiro: Jorge Zahar.

Lacan, J. (1998). Escritos. Rio de Janeiro: Editora Zahar.

Lacan, J. (2003). Televisão. In J. Lacan (Ed.), Outros escritos (pp. 508-544). Rio de Janeiro: Jorge Zahar.

Mbembe, A. (2018). Necropolítica. Rio de Janeiro: N-1 Edições.

Miller, J. A. (2010). Le salut par le déchet. Mental: Clinique et pragmatique de la désinsertion en psychanalyse, $\mathrm{n}^{\circ} 24,9-15$.

Munanga, K. (1990). Negritude afro-brasileira: perspectivas e dificuldades. Revista De Antropologia, 33, 109-117. Retrieved from: http://www.revistas.usp.br/ra/issue/view/8417/587

Munanga, K. (2004). Programa de Educação Sobre o Negro na Sociedade Brasileira. Niterói: EDUFF.

Munanga, K. (2017). Ambiguidades do Racismo à brasileira. In N. M. Kon; M. L. da Silva; C. C. Abud (orgs). O Racismo e o Negro no Brasil: Questões para a Psicanálise (pp.3345). São Paulo: Perspectiva.

National Park Service, Women's Rights National Historical Park (2017, 17 November). Sojourner Truth, Ain't I A Woman, Women's Rights Convention, Old Stone Church, Akron, Ohio, 1851. Retrieved from https://www.nps.gov/articles/sojourner-truth.htm

Nogueira, I. B. (1998). Significações do Corpo Negro. PHD Thesis. Universidade de São Paulo, Brazil. Retrieved from: http://www.ammapsique.org.br/baixe/corpo-negro.pdf

Schwarcz, L, M. (1996). Ser peça, ser coisa: definições e especificidades da escravidão no Brasil. In L. M. Schwarcz \& L.V.S. Reis (Eds.) Negras Imagens (pp. 11-29). São Paulo: EDUSP

Silva, M. L. da (2017). Racismo no Brasil: Questões para Psicanalistas Brasileiros. In N. M. Kon; M. L. da Silva; C. C. Abud (orgs). O Racismo e o Negro no Brasil: Questões para a Psicanálise (pp. 71-91). São Paulo: Perspectiva.

Souza, N. S. (1983). Tornar-se Negro: As Vicissitudes da Identidade do Negro Brasileiro em Ascensão Social. Rio de Janeiro: Edições Graal. 
Jefferson Nascimento é mestrando em Psicologia pela Universidade Federal Fluminense, artista bailarino, profissional da rede pública de saúde mental do Rio de Janeiro e psicanalista.

$\bowtie$ jefferson.donascimento@outlook.com

Giselle Falbo é professora do Instituto de Psicologia da Universidade Federal Fluminense. Professora do Programa de Pós-Graduação em Psicologia da mesma universidade. Doutora pelo Programa de Pós-Graduação em Teoria Psicanalítica da Universidade Federal do Rio de Janeiro e psicanalista.

凶 falbogiselle@gmail.com 